\title{
Identification of Genes Regulated by IL-1 $\beta$ Using Integrative microRNA and mRNA Genomic Analysis in Human Articular Chondrocytes
}

\author{
Hyun Ah Kim ${ }^{1}$, Hyun A Jung ${ }^{1}$, Tae Young Kim ${ }^{2}$ \\ Departments of ${ }^{1}$ Internal Medicine, ${ }^{2}$ Orthopedic Surgery, \\ Hallym University Sacred Heart Hospital, Anyang, Korea
}

Objective. The physiological and pathogenetic role of microRNAs (miRNAs) in the maintenance of joint homeostasis and in the development of arthritis is recently being elucidated. In this study, we attempted to identify differentially expressed miRNAs in human osteoarthritis (OA) chondrocytes in response to interleukin (IL)-1 $\beta$. In addition, simultaneous profiling of miRNA and mRNA expression was performed to get an integrated analysis of miRNA and mRNA expression.

Methods. Monolayer cultured chondrocytes obtained from knee cartilages of OA patients were stimulated with IL-1 $\beta$ for 4 hours and RNA was isolated. One microgram of total RNA was polyadenylated and converted to CDNA and miRNA microarray was performed. Seven hundred thirty five oligos were used, corresponding to 470 well-annotated human miRNA sequences and 265 potential miRNAs that were identified recently. mRNA microarray was performed simultaneously using the RNA samples that were

\section{Introduction}

Osteoarthritis (OA) is a degenerative disease of articular cartilage and causes significant morbidity in humans. It is characterized by loss of articular cartilage matrix, mainly collagen and proteoglycans, leading to tissue destruction and cell death, eventually resulting in loss of joint function. Although OA is frequently regarded as a noninflammatory form of arthritis, considerable data implicate a role of proinflammatory cytokines derived from both the synovium and the chondrocytes in cartilage destruction. The proinflammatory cytokine inter-

<Received : April 12, 2011, Revised: July 20, 2011, Accepted: July 22, 2011>

Correspondence : Hyun Ah Kim

Division of Rheumatology, Department of Internal Medicine, Hallym University Sacred Heart Hospital 896, Pyongchon-dong, Dongan-gu, Anyang 431-070 Korea

E-mail : kimha@hallym.ac.kr used for miRNA array. Both sequence and expression information was used to identify regulatory relationship between miRNA and mRNA pairs.

Results. Expression profiling of miRNA extracted from IL-1 $\beta$ treated chondrocytes identified 25 miRNA which showed differential expression. We also identified 7190 mRNAs differentially regulated by IL-1 $\beta$ treatment. Among the 25 miRNAs differentially regulated, 13 miRNAs had targets searched by MiRANDA scheme. By combining target search and miRNA-mRNA pairing, we could identify 1043 miRNA-mRNA target pairs. MiR-200a was found to be expressed in human $\mathrm{OA}$ and normal cartilages, with downregulation in $\mathrm{OA}$ lesion cartilages.

Conclusion. It is suggested that miRNA may play a role in the regulation of cartilage degradation in OA.

Key Words. Chondrocytes, Interleukin-1, microRNA, miR200a, mRNA, Osteoarthritis

leukin (IL)-1 $\beta$ and its downstream mediators lead to the upregulation of matrix metalloproteinase (MMP), and a decrease in the synthesis of cartilage extracellular matrix (ECM) (1). IL-1 $\beta$ also induces a cascade of intracellular intermediates that are postulated as important players in the inflammatory pathway of OA, such as inducible nitric oxide synthase (iNOS), cyclooxygenase 2 (COX-2) and phospholipase $\mathrm{A}_{2}$ (2). A variety of therapeutic strategies for OA have thus been developed to antagonize the activity of IL-1 $\beta$ and its downstream targets. A detailed analysis of the extent of regulation of chondrocyte function by IL-1 $\beta$ would be indispensable for such strategies to be effective and safe.

MicroRNA (miRNA)s are short endogenous oligonucleotides $(\sim 22 \mathrm{bp})$ with a profound role in the regulation of post-transcriptional gene expression. miRNAs regulate their targets both by translational inhibition and acceleration of mRNA degradation (3). Target genes are determined by sequence complementarity between the 3'-untranslated region (UTR) 
and the mature miRNA, particularly in a 6bp 'seed' region (4). Currently, 1,100 human miRNAs are registered in the miRBase database (release 16, September 2010) and each miRNA is expected to target around 200 transcripts (5). Predictive algorithms suggest that up to a third of all human genes contain putative miRNA recognition elements (6). The finding that miRNAs regulate multiple genes and the demonstration of differential expression of miRNA in animal cells and tissues has led to speculation that their control of gene expression is conceptually similar to the action of transcription factors although they act at the translational level (7).

Evidences have been accumulated recently that miRNAs play critical roles in diverse biological processes including development and cancer. Since miRNAs can affect mRNA levels, they might leave a signature on the mRNA expression profile in a specific tissue or biological condition. Therefore, it is suggested that simultaneous profiling of miRNA and mRNA expression may be a plausible way to predict functional miRNA targets. Previously, it was reported that paired expression profiling of miRNA and mRNA identify a network of 1597 high-confidence target predictions for 104 human miRNAs across 88 tissues and cell types with high precision (8).

In this study, we attempted to identify differentially expressed miRNAs in human OA chondrocytes in response to IL- $1 \beta$. In addition, simultaneous profiling of miRNA and mRNA expression was performed for an integrated analysis of miRNA and mRNA expression.

\section{Materials and Methods}

\section{Reagents}

Dulbecco's modified Eagle medium (DMEM), fetal calf serum, and Fungizone were obtained from Gibco (Grand Island, NY). Human recombinant IL-1 $\beta$ was obtained from R \& D Systems (Minneapolis, MN). TRIzol was obtained from Invitrogen Life Technologies (Carlsbad, CA). All other reagents were obtained from Sigma (St. Louis, MO) unless otherwise specified.

\section{Chondrocyte monolayer culture}

Cartilage samples were obtained from the femoral condyle and tibial plateau of the knee from OA patients at the time of joint replacement surgery. The collection and use of human samples were reviewed and approved by the Institutional Review Board of Hallym University Sacred Heart Hospital (Anyang, Korea). Full-thickness cartilage slices were obtained from above the subchondral bone from a relatively lesion-free area. Chondrocytes were cultured in monolayer as was described previously (9). Briefly, slices were minced and in- cubated sequentially with pronase and collagenase and released cells were seeded at a density of $5 \times 10^{6} /$ plate in $10 \mathrm{~cm}$ culture plates in DMEM supplemented with $10 \%$ fetal calf serum, $1 \%$ L-glutamine, $1 \%$ Fungizone and penicillin/streptomycin (150 units $/ \mathrm{mL}$ and $50 \mathrm{mg} / \mathrm{mL}$ each). After about 7 days, confluent chondrocytes were split once, seeded at high density and these first passage chondrocytes were used within 2 days in subsequent experiments. Chondrocytes were incubated with DMEM containing $0.5 \%$ fetal calf serum for 16 hours prior to treatment with IL-1 $\beta \quad(1 \mathrm{ng} / \mathrm{mL})$.

\section{RNA preparation}

RNA was isolated with TRIzol from cultured chondrocytes 4 hours after treatment with IL-1 $\beta$, and purified using mirVANA kit according to the instructions of the manufacturer (Applied Biosystems, Foster City, CA). For quality control, RNA purity and integrity were evaluated by denaturing gel electrophoresis and optical density (OD) 260/280 ratio.

\section{microRNA and mRNA microarray}

One microgram of total RNA was polyadenylated and converted to cDNA using poly-A polymerase, polyadenylation reaction reagent, and cDNA synthesis reagent (Illumina, San Diego, CA). One miRNA-specific oligo containing a universal PCR priming site, an address sequence that complements a corresponding capture sequence on the array, and a microRNA-specific sequence was used to assay each microRNA. Seven hundred thirty five oligos were used, corresponding to 470 well-annotated human microRNA sequences and 265 potential microRNAs that were identified recently. After labeling the DNA with fluorolink streptavidin-Cy3 (Molecular Probes, Carlsbad, CA), hybridization was conducted under a temperature gradient program from $60^{\circ} \mathrm{C}$ to $45^{\circ} \mathrm{C}$ over 14 hours. After hybridization, the arrays were rinsed and then imaged at a resolution of 0.8 microns using a BeadArray Reader (Illumina). For mRNA microarray, the same RNA samples used in miRNA microarray were amplified and purified using the RNA amplification kit (Ambion, Austin, TX) to yield biotinylated cRNA according to the manufacturer's instructions. Seven hundred fifty nanogram of labeled cRNA samples were hybridized to each human HT-12 expression bead array for $16 \sim 18 \mathrm{~h}$ at $58^{\circ} \mathrm{C}$, according to the manufacturer's instructions (Illumina). Detection of array signal was carried out using Cy3 following the bead array manual.

\section{Microarray data analysis}

For both mRNA and miRNA expression arrays, the quality of hybridization and overall chip performance were monitored 
by visual inspection of both internal quality control checks and the raw scanned data. To identify differentially expressed mRNA and miRNA, we used Student t-test. To adjust multiple testing problems, we estimated the proportion of false positives by using the false discovery rates which was controlled by Benjamini and Hochberg algorithm (10). All of statistical analyses were performed using $\mathrm{R}$ statistical language.

\section{Sequence \& expression based miRNA target prediction}

We used both sequence and expression information to identify regulatory relationship between miRNA and mRNA pairs. We downloaded miRNA-mRNA target pair data estimated by miRanda algorithm (11), based on local sequence alignment. Among differentially expressed miRNAs and mRNAs that were identified by statistical analysis of microarray data, we searched for the miRNA-mRNA target pairs predicted by miRanda algorithm.

\section{Reverse transcription polymerase chain reaction (RT-PCR)}

To validate the miRNA microarray data, quantitative real-time RT-PCR analysis for selected miRNA was performed. Total RNA was isolated from IL-1 $\beta$ treated monolayer chondrocytes obtained from donors different from those that were used in miRNA microarray. Expression of miR-200a was assessed using a TaqMan MicroRNA Assay protocol (Applied Biosystems). cDNA was synthesized from $2 \mu \mathrm{g}$ of total RNA using miRNA specific primers and the TaqMan MicroRNA Reverse Transcription Kit (both from Applied Biosystems). Real-time RT-PCR was performed using an Applied Biosystems 7900HT Sequence Detection System in a $20-\mu \mathrm{L}$ PCR mixture containing $1.33 \mu \mathrm{L}$ of RT product, $10 \mu \mathrm{L}$ TaqMan Universal PCR Master Mix, $1 \mu \mathrm{L}$ Taqman microRNA assay reagent containing forward and reverse primers and $7.67 \mu \mathrm{L}$ nuclease free water. All reactions were incubated in a 96 -well plate at $95^{\circ} \mathrm{C}$ for 10 minutes, followed by 45 cycles of $95^{\circ} \mathrm{C}$ for 15 seconds, $60^{\circ} \mathrm{C}$ for 30 seconds and $72^{\circ} \mathrm{C}$ for 1 second; all reactions were performed in triplicate. The RNA, U6 small nuclear 2 (RNU6-2) gene was used as a control to normalize differences in total RNA levels in each sample. A threshold cycle $\left(\mathrm{C}_{\mathrm{t}}\right)$ was observed in the exponential phase of amplification, and quantification of relative expression levels was performed using standard curves for target genes and the endogenous control. Geometric means were used to calculate the $\Delta \Delta \mathrm{C}_{\mathrm{t}}$ values and were expressed as $2^{-\Delta \Delta \mathrm{Ct}}$. Data are given as fold changes of average signals in control and IL-1 $\beta$ treated chondrocytes. mRNA microarray data were validated by semi-quantitative RT-PCR analysis for selected genes. Total RNA was isolated from IL-1 $\beta$ treated monolayer chondrocytes obtained from do- nors different from those that were used in mRNA microarray. To assess the expression of TNS1 and Tbx15, cDNA was synthesized from $2 \mu \mathrm{g}$ of total RNA using MMLV reverse transcriptase (Promega, WI, USA). One $\mu \mathrm{L}$ of the RT product was used as a template for PCR amplification of TNS1, Tbx15, and GAPDH using the following cycles: TNS 1 and $\mathrm{Tbx} 15,94^{\circ} \mathrm{C}$ for $40 \mathrm{sec}, 55^{\circ} \mathrm{C}$ for $40 \mathrm{sec}$, and $72^{\circ} \mathrm{C}$ for 1 minute for over 26 28 cycles; GAPDH, $94^{\circ} \mathrm{C}$ for $40 \mathrm{sec}, 55^{\circ} \mathrm{C}$ for $40 \mathrm{sec}$, and $72^{\circ} \mathrm{C}$ for 1 minutes for over 20 cycles. Primer pairs were as follows: TNS1, sense 5'-TAAACAGCTCGGCTTGTCCT-3' and antisense 5'-GGAGCAACTTGCCTTTCTTG-3'; Tbx15, sense 5'-TAACCAACAGGCAACCAACA-3' and antisense 5'-CTCT TCAAAGGCCACTCTGG-3'; GAPD H, sense 5'-GAAGGTGA AGGTCGGAGTCA-3' and antisense 5'-GAAGATGGTGATGG GATTTC-3.' PCR products were separated by electrophoresis on a $1.5 \%$ agarose gel and were visualized by ethidium bromide staining.

\section{In situ hybridization}

Cartilage tissues obtained from OA patients at the time of joint replacement surgery were cut to the subchondral bone from both lesion and non-lesion areas (defined as areas with preserved cartilage surface and thickness), immediately fixed with $4 \%$ paraformaldehyde and embedded in paraffin. For non-OA cartilage, macro and microscopically normal cartilage samples obtained from the femoral head of patients with femoral neck fracture were used. After dewaxing and dehydration, sections were washed in phosphate buffered saline (PBS) and deproteinated with proteinase $\mathrm{K}\left(10 \mu \mathrm{g} / \mathrm{mL}\right.$ at $\left.37^{\circ} \mathrm{C}\right)$. Sections were washed once in $0.2 \%$ glycine in PBS and twice in PBS. Prehybridization was performed in a humidified chamber (50\% formamide, 5X SSC) using hybridization buffer $(50 \%$ formamide, $5 \mathrm{X}$ SSC, $0.1 \%$ Tween, $9.2 \mathrm{mM}$ citric acid adjusted to $\mathrm{pH} 6,50 \mu \mathrm{g} / \mathrm{mL}$ heparin, and $500 \mu \mathrm{g} / \mathrm{mL}$ yeast RNA) for 2 hours. Slides were then hybridized overnight with $20 \mathrm{nM}$ of FITC-labeled probes for miR-200a (CACA AACCATTATGTGCTGCTA) or scrambled miRNA (TTCAC AATGCGTTATCGGATGT) in a humidified chamber at $65^{\circ} \mathrm{C}$. Sections were rinsed in $5 \mathrm{x}$ SSC for 30 minutes at $65^{\circ} \mathrm{C}$, $0.2 \mathrm{x}$ SSC for 2 hours at $65^{\circ} \mathrm{C}$, and $0.2 \mathrm{x}$ SSC for 5 minutes at room temperature.

\section{Data analysis}

Data are expressed as means \pm SDs. Differences between treatment groups were tested by using the Mann-Whitney U test (GraphPad Prism, version 3, GraphPad Software, San Diego, CA). Significance was established at the $95 \%$ confidence level $(\mathrm{p}<0.05)$. 
Table 1. MiRNAs with differential expression between IL-1 $\beta$ treated and control chondrocytes from OA cartilages $(n=6)$

\begin{tabular}{lcc}
\hline \multicolumn{1}{c}{ miRNA } & $\begin{array}{c}\text { Chromosomal } \\
\text { location }\end{array}$ & Fold change \\
\hline tHS_15.1 & Unknown & 2.15 \\
HS_176 & 11 & 2.01 \\
HS_221 & 15 & 1.63 \\
hsa-miR-202 & 10 & 1.52 \\
hsa-miR-335 & 7 & 1.48 \\
hsa-miR-563 & 3 & 1.46 \\
hsa-miR-362 & $\times$ & 1.39 \\
hsa-miR-452 & $\times$ & 1.38 \\
HS_149 & 9 & 1.36 \\
hsa-miR-603 & 10 & 1.35 \\
HS_175 & 11 & 1.29 \\
hsa-miR-425 & 3 & 1.24 \\
HS_219 & 15 & 1.16 \\
hsa-miR-507 & $\times$ & 1.16 \\
hsa-miR-766 & $\times$ & 1.15 \\
HS_145.1 & 9 & 1.08 \\
hsa-let-7e & 19 & 1.04 \\
hsa-miR-31 & 9 & -1.06 \\
hsa-miR-454-3p & 17 & -1.11 \\
hsa-miR-181b & 9 & -1.25 \\
hsa-miR-565 & 3 & -1.28 \\
hsa-miR-200a & 1 & -1.42 \\
hsa-miR-449 & 5 & -1.42 \\
HS_141 & 10 & -1.46 \\
hsa-miR-594 & 7 & -1.53 \\
\hline
\end{tabular}

Positive fold change values indicate elevated expression and negative fold change values indicate decreased expression in IL-1 $\beta$ treated chondrocytes compared to control.

\section{Results}

Expression profiling of 735 human miRNA extracted from IL-1 $\beta$ treated chondrocytes $(n=6)$ identified 25 miRNA which showed differential expression between control and treated cells (Table 1). Overall, the difference in expression was modest, and only 2 miRNAs showed more than 2 fold difference in expression level between control and treated samples (HS_176, tHS_15.1). We also identified 7190 mRNAs differentially regulated by IL- $\beta$ treatment. Large numbers of mRNA encoding proinflammatory and catabolic mediators previously reported to be regulated by IL- $1 \beta$ were identified by the mRNA microarray, including MMP-13, inducible nitric oxide synthase, IL-6, tumor necrosis factor (TNF)-alpha and various chemokines (data not shown). Among the 25 miRNAs differentially regulated, 14 miRNAs had targets searched by MiRANDA scheme. By combining target search and miRNAmRNA pairing, we could identify 1043 miRNA-mRNA target pairs. Table 2 and 3 shows selected pairs of miRNA-mRNA relevant in the cartilage biology and arthritis.

We selected one downregulated miRNA, miR-200a and examined their expression in human articular chondrocytes and cartilages. In line with the miRNA microarray result, monolayer cultured OA chondrocytes treated with IL-1 $\beta$ showed downregulation of miR-200a, when miRNA level was examined by real-time RT-PCR (Fig. 1). The expression levels of 2 selected target genes for miR-200a, T-box 15 (tbox-15), a transcription factor regulating proliferation of chondrocytes (52), and tensin

Table 2. MiRNAs upregulated by IL-1 $\beta$ and their target mRNAs identified by integrative analysis

\begin{tabular}{|c|c|c|}
\hline $\begin{array}{l}\text { MicroRNA } \\
\text { (upregulated) }\end{array}$ & $\begin{array}{c}\text { mRNA } \\
\text { (downregulated) }\end{array}$ & Comments \\
\hline \multirow[t]{4}{*}{ Let-7e } & $\begin{array}{l}\text { GSPT1 (G1 to S phase } \\
\text { transition 1) }\end{array}$ & $\begin{array}{l}\text { Controls G1 to the S phase transition; downregulated in chondrocyte redifferentiation in } \\
\text { 3D pellet culture (12) }\end{array}$ \\
\hline & $\begin{array}{l}\text { SOCS1 (suppressors of } \\
\text { cytokine signaling 1) }\end{array}$ & Induced by FGF; up-regulated in the synovial membranes from patients with RA (13) \\
\hline & $\begin{array}{l}\text { SNX19 (sorting } \\
\text { nexin 19) }\end{array}$ & $\begin{array}{l}\text { Expressed in the limb cartilage of mouse embryos and in the degraded cartilage of adult } \\
\text { mouse knee joints during osteoarthritis progression; a potent chondrogenic stimulator (14) }\end{array}$ \\
\hline & $\begin{array}{l}\text { CLP1 (cleavage and } \\
\text { polyadenylation factor } \\
\text { I subunit homolog) }\end{array}$ & Stimulates cell proliferation in rabbit articular chondrocytes (15) \\
\hline \multirow[t]{4}{*}{ miR-335 } & CASP7 (caspase7) & Elicited in human articular chondrocytes by sodium nitroprusside (16) \\
\hline & Hoxd13 (homeobox D13) & Development of the forelimb and hindlimb autopod in mice (17) \\
\hline & TLR1 (Toll-like receptor 1 ) & Pattern recognition receptor involved in innate immunity \\
\hline & $\begin{array}{l}\text { TIAM1 (T-cell lymphoma } \\
\text { invasion and metastasis } 1 \text { ) }\end{array}$ & $\begin{array}{l}\text { Down-regulated in high pressure culture and upregulated in cyclic stretching culture in } \\
\text { chondrosarcoma line (18); linked with hyaluronan metabolism (19) }\end{array}$ \\
\hline \multirow[t]{2}{*}{$\operatorname{miR}-425$} & TNC (Tenascin) & $\begin{array}{l}\text { Oligomeric glycoprotein of the extracellular matrix; upregulated in tissues at } \\
\text { developmental stages, during wound healing, and during tumorigenesis; upregulated in } \\
\text { neonatal cartilage (20) }\end{array}$ \\
\hline & IL4R (IL4 receptor) & $\begin{array}{l}\text { Involved in the anabolic response of chondrocytes from normal articular cartilage; } \\
\text { chondroprotective in cartilage biology and play a central role in the maintenance of the } \\
\text { extracellular matrix (21) }\end{array}$ \\
\hline
\end{tabular}


Table 2. Continued

\begin{tabular}{|c|c|c|}
\hline $\begin{array}{l}\text { MicroRNA } \\
\text { (upregulated) }\end{array}$ & $\begin{array}{c}\text { mRNA } \\
\text { (downregulated) }\end{array}$ & Comments \\
\hline \multirow{4}{*}{ miR-563 } & VIM (Vimentin) & $\begin{array}{l}\text { A member of the intermediate filament family, which make up the cytoskeleton; maintains } \\
\text { cell shape, integrity of the cytoplasm, and stabilizes cytoskeletal interactions; decreased } \\
\text { in chondrosarcoma cells in cyclic and continuous hydrostatic pressure (19); higher } \\
\text { expression in nucleus pulposus than in articular cartilage of rat (22) }\end{array}$ \\
\hline & $\begin{array}{l}\text { FGF18 (fibroblast } \\
\text { growth factor } 18 \text { ) }\end{array}$ & $\begin{array}{l}\text { Possess broad mitogenic and cell survival activities, and are involved in embryonic } \\
\text { development, cell growth, morphogenesis, tissue repair, tumor growth, and invasion; } \\
\text { plays a role in the maintenance of chondrocyte properties (23); stimulates chondrogenesis } \\
\text { and cartilage repair in a rat model of injury-induced osteoarthritis (24) }\end{array}$ \\
\hline & $\begin{array}{l}\text { HAS3 (hyaluronan } \\
\text { synthase } 3 \text { ) }\end{array}$ & $\begin{array}{l}\text { Involved in the synthesis of the unbranched glycosaminoglycan hyaluronan, or hyaluronic } \\
\text { acid, which is a major constituent of the extracellular matrix;upregulated by IL-1 in } \\
\text { bovine chondrocytes (25) }\end{array}$ \\
\hline & IL7R (IL-7 receptor) & $\begin{array}{l}\text { Blocking apoptosis during differentiation and activation of } \mathrm{T} \text { lymphocytes; respond to } \mathrm{IL}-7 \\
\text { stimulation with increased production of matrix metalloproteinase-13 and with } \\
\text { proteoglycan release from cartilage explants (26) }\end{array}$ \\
\hline
\end{tabular}

phase transition 1)

FOXC2 (forkhead

box $\mathrm{C} 2$ )

miR-603 Lyn (v-yes-1 Yamaguchi sarcoma viral related oncogene homolog)

MAX (MYC associated factor $\mathrm{X}$ )

POR (P450 (cytochrome) oxidoreductase)

The forkhead family of transcription factors which may play a role in the development of mesenchymal tissues; associated with the early stage of chondrogenic differentiation; regulated by BMP in skeletal precursor cells (27)

A Src kinase gene which upon T-cell antigen receptor (TCR) stimulation, functions in the initial step of TCR-mediated signal transduction; inhibition by Src kinase inhibitor promotes chondrogenic gene expression and morphology in monolayer culture (28)

A member of the basic helix-loop-helix leucine zipper family of transcription factors, which forms homodimers and heterodimers with Mad, Mxi1 and Myc; expressed mainly in the nucleus of proliferative chondrocytes and decreased as the chondrocytes mature (29)

An endoplasmic reticulum membrane oxidoreductase which donate electrons directly from NADPH to all microsomal P450 enzymes; mutations in this gene have been associated with amenorrhea and disordered steroidogenesis, congenital adrenal hyperplasia and Antley-Bixler syndrome; specific inhibition leads to decreased cell proliferation and differentiation and induction of apoptosis in rat chondrocytes with decreased intracellular cholesterol content and Indian hedgehog expression (30)

NKX3-1 (NK3 homeobox 1) A transcription factor which is a putative prostate tumor suppressor expressed in a largely prostate-specific and androgen-regulated manner; act together with Sox9 to maintain the chondrogenic cell fate and promote early differentiation (31)

miR-766 PTGER2 (prostaglandin E receptor 2)

A receptor for prostaglandin E2; decreased by IL-1 in human chondrocytes (32); stimulation of human articular chondrocytes with PGE2 through the EP2 receptor suppresses proteoglycan accumulation and synthesis, aggrecan gene expression and decreases the type II collagen:type I collagen ratio; expressed at higher levels in knee cartilage than in ankle cartilage and in a OA grade-dependent manner (33); a specific EP2 agonist promotes regeneration of cartilage tissues with a physiological osteochondral boundary in rabbit injury models (34)

SDC4 (Syndecan 4)

A transmembrane (type I) heparan sulfate proteoglycan that functions as a receptor in intracellular signaling; the mRNA level increase in cartilage tissue from heavily damaged area of human OA (35); specifically induced in type X collagen-producing chondrocytes both in human and in murine OA; knock-out mice are protected from cartilage damage in a surgically induced model of OA by decrease in ADAMTS-5 activity (36); interact with MMP-13 C-terminal domain in cultured human chondrocytes (37)

SAT1 (spermidine/spermine N1-acetyltransferase 1)

A rate-limiting enzyme in the catabolic pathway of polyamine metabolism catalyzing the acetylation of spermidine and spermine, and involved in the regulation of the intracellular concentration of polyamines and their transport out of cells; increase in activity by parathyroid hormone (PTH) in rabbit costal chondrocytes (38) 
1, a protein crosslinking actin filaments and regulating cytoskeletone rearrangement (51) were validated by RT-PCR (Fig. 2). IL-1 dose-dependently upregulated these 2 genes in articular chondrocytes. Lastly, the expression of miR-200a was examined in normal and OA cartilages from lesion and non-lesion area (Fig. 3). It was found that the expression of miR-200a was scant in the superficial zone compared to the deep zone in both nor- mal and OA non-lesion cartilages. In OA lesion cartilage, the expression of miR-200a was downregulated.

\section{Discussion}

In this study, we identified miRNAs differentially regulated by IL-1 $\beta$ in human OA articular chondrocytes. By using integrative approach using simultaneous miRNA-mRNA profil-

Table 3. MiRNAs downregulated by IL-1 $\beta$ and their target mRNAs identified by integrative analysis

\begin{tabular}{ccc}
\hline \hline $\begin{array}{c}\text { MicroRNA } \\
\text { downregulated }\end{array}$ & mRNA & Comments \\
\hline
\end{tabular}

miR-181b GPI (glucose Multifunctional phosphoglucose isomerase protein involved in energy pathways; implicated as phosphate isomerase) an autoantigen in rheumatoid arthritis; conformational changes under acidic conditions, such as those encountered in the synovial fluid of arthritic joints, results in increased association and deposition of fibronectin fibrils on the joint surface (39)

GSTA-4 (glutathione Involved in cellular defense against toxic, carcinogenic, and pharmacologically active S-transferase alpha 4) electrophilic compounds; ablation augments 4-hydroxynonenal cytotoxicity in human OA chondrocytes (40)

P4HA2 (prolyl A key enzyme in collagen synthesis which catalyzes the formation of 4-hydroxyproline essential 4-hydroxylase, alpha polypeptide II) to the proper three-dimensional folding of newly synthesized procollagen chains; exposure of primary human articular chondrocytes to $1 \%$ oxygen increase transcript levels, while treatment with 2-methoxyestradiol reduce transcriptional activity (41)

PTHR1 (parathyroid A receptor for parathyroid hormone(PTH) and for parathyroid hormone-like hormone; expressed hormone receptor 1) principally by proliferative and prehypertrophic chondrocytes in endochondral growth (42); increase by co-culture of human articular chondrocytes with non-sclerotic subchondral osteoblast (43); activation of PTH/PTHrP receptor signaling by hPTH results in the inhibition of chondrogenic differentiation in full-thickness articular cartilage defects (44); delays chondrocyte hypertrophy mediated by both Runx2-dependent and -independent mechanisms (45)

MAP3K6 (mitogenactivated protein kinase kinase kinase 6) SLC26A11 (solute carrier family 26 , member 11)

miR-200a
RBL2 (retinoblastomalike 2 (p130))

STMN1 (stathmin 1)

PBX1 (pre-B-cell leukemia homeobox 1)

PTHR1

TEN (Tensin 1)

Tbx15 (T-box-15)
A member of the serine/threonine protein kinase family; weakly activate MAPK7, but not MAPK1/ERK or MAPK14

A sodium independent sulfate transporter; a member of the solute linked carrier 26 family of anion exchangers; essential for homeostasis and intracellular electrolyte balance; expressed in bovine articular chondrocytes, and regulates sulfate uptake, an essential step in the pathway for sulphation of glycosaminoglycans (46)

Contributes to cell cycle exit, and knock out leads to deregulated proliferation, reduced expression of Cbfa1, and reduced hypertrophic differentiation of chondrocytes (47); effectors of FGF-mediated growth inhibition in chondrocytes (48)

A ubiquitous cytosolic phosphoprotein, involved in the regulation of the microtubule filament system by destabilizing microtubules; proliferating chondrocytes in vivo exhibit higher level of stathmin than either resting or growth zone in the growth plate (49)

A component of various protein complexes implicated in developmental gene expression; knock-out leads to embryonic death with widespread patterning defects of the axial and appendicular skeleton, decrease in chondrocyte proliferation, and an increase in hypertrophic chondrocytes (50)

Localizes to focal adhesions and crosslinks actin filaments; a substrate of calpain II; upregulated by BMP in bovine and murine chondrocytes (51)

A phylogenetically conserved family of transcription factors that regulate a variety of developmental processes; expressed during limb development in the early limb bud, in prehypertrophic chondrocytes of cartilaginous templates, and in mesenchymal precursor cells and prehypertrophic chondrocytes of the vertebral column and the head of mouse embryo; mutants display a general reduction of bone size, changes of bone shape, reduction in the size of cartilaginous templates, and reduction in proliferation of prehypertrophic chondrocytes (52) 
Table 3. Continued

\begin{tabular}{|c|c|c|}
\hline $\begin{array}{c}\text { MicroRNA } \\
\text { downregulated }\end{array}$ & $\begin{array}{l}\text { mRNA } \\
\text { upregulated }\end{array}$ & Comments \\
\hline \multirow[t]{6}{*}{$\operatorname{miR}-31$} & $\begin{array}{l}\text { HTRA1 (HtrA serine } \\
\text { peptidase 1) }\end{array}$ & $\begin{array}{l}\text { Member of the trypsin family of serine proteases; regulates the availability of insulin-like } \\
\text { growth factors (IGFs) by cleaving IGF-binding proteins; increased in the knee and TM joints } \\
\text { of mouse OA models in early stages of the disease (53); HtrA1-generated aggrecan fragments } \\
\text { containing the VQTV (356) neoepitope were significantly more abundant in osteoarthritic } \\
\text { cartilage compared with cartilage from healthy joints (54) }\end{array}$ \\
\hline & $\begin{array}{l}\text { FGFR3 (fibroblast } \\
\text { growth factor } \\
\text { receptor } 3 \text { ) }\end{array}$ & $\begin{array}{l}\text { Binds acidic and basic fibroblast growth hormone and plays a role in bone development and } \\
\text { maintenance; mutation leads to achondroplasia; induces premature senescence in chondrocytes, } \\
\text { manifested as growth arrest, alteration of cellular shape, and loss of the extracellular matrix (55) }\end{array}$ \\
\hline & $\begin{array}{l}\text { CYTL1 } \\
\text { (cytokine-like 1) }\end{array}$ & $\begin{array}{l}\text { Expressed in bone marrow and cord blood mononuclear cells; regulates chondrogenesis as a } \\
\text { novel autocrine factor, but not hypertrophic maturation of chondrocytes during cartilage } \\
\text { development (56) }\end{array}$ \\
\hline & $\begin{array}{l}\text { HOXA2 (homeobox } \\
\text { A2) }\end{array}$ & $\begin{array}{l}\text { Encodes a DNA-binding transcription factor which may regulate morphogenesis, and } \\
\text { differentiation; the encoded protein may be involved in the placement of hindbrain segments } \\
\text { in the proper location along the anterior-posterior axis during development; persistent } \\
\text { expression in chondrogenic cells results in overall chondrodysplasia with delayed cartilage } \\
\text { hypertrophy, mineralization, and ossification in mouse embryo (57) }\end{array}$ \\
\hline & $\begin{array}{l}\text { GPX7 (glutathione } \\
\text { peroxidase } 7 \text { ) }\end{array}$ & $\begin{array}{l}\text { An antioxidant enzyme that disproportionate reactive oxygen species; increased by IL-1 and } \\
\text { IL-6 dose and time-dependently in bovine chondrocytes (58) }\end{array}$ \\
\hline & $\begin{array}{l}\text { CDK4 (cyclin- } \\
\text { dependent kinase 4) }\end{array}$ & $\begin{array}{l}\text { A catalytic subunit of the protein kinase complex important for cell cycle G1 phase progression; } \\
\text { overexpression leads to resistance to FGF-induced p107 dephosphorylation and growth arrest (59) }\end{array}$ \\
\hline \multirow[t]{3}{*}{$\operatorname{miR}-565$} & ENG (endoglin) & $\begin{array}{l}\text { A major glycoprotein of the vascular endothelium,and a component of the transforming growth } \\
\text { factor (TGF) beta receptor complex; mutations in this gene cause hereditary hemorrhagic } \\
\text { telangiectasia; expressed on human chondrocytes at levels comparable with endothelial cells } \\
\text { and forms higher order complexes with the type I and II TGF } \beta \text { receptors (60) }\end{array}$ \\
\hline & $\begin{array}{l}\text { BARX1 (BARX } \\
\text { homeobox 1) }\end{array}$ & $\begin{array}{l}\text { A member of the Bar subclass of homeobox transcription factors which play a role in developing } \\
\text { teeth and craniofacial mesenchyme of neural crest origin; expressed in the developing joint } \\
\text { and articular cartilage and has an inhibitory effect on chondrogenic initiation (61) }\end{array}$ \\
\hline & CTSK (cathepsin K) & $\begin{array}{l}\text { A lysosomal cysteine proteinase involved in bone remodeling and resorption; induced in } \\
\text { phenotypically altered chondrocytes in human OA and animal OA model }(62,63) \text {; chemical } \\
\text { inhibitor results in mild to moderate beneficial effects on gross and histopathological } \\
\text { parameters of OA and reduction of biomarkers of collagen type I and II degradation in the } \\
\text { canine partial medial meniscectomy model of OA (64) }\end{array}$ \\
\hline
\end{tabular}

ing and bioinformatic analysis, we further attempted to explore the miRNA target with more precision.

Precise identification of miRNA targets is important for elucidation of the pathogenesis of human diseases resulting from miRNA misregulation. Although miRNAs are believed to regulate their targets primarily through inhibition of translation, increasing evidence shows that miRNAs also influence the amount of their target mRNAs. In both mammalian and Drosophila systems, miRNAs have been shown to accelerate target mRNA degradation through the pathway of deadenylation, consequently decreasing target mRNA abundance (5). The rules that govern miRNA target specificity remain elusive. Several computational methods have been developed to predict mRNAs targeted by miRNAs in animals. One of such methods is TargetScan, which was applied to predict miRNA target sites conserved among orthologous 3' UTRs of vertebrates (65). When using 3' UTR regions of human, mouse, and rat, 451 human targets were predicted by TargetScan using score and rank cutoffs, but it gave as many as $31 \%$ false-positive predictions (65). The fact that miRNAs cause degradation of their targets and that a large number of mRNAs are regulated in this way leads to the prediction that a miRNA expressed at a high or low level in a specific cell or tissue might leave a signature on the mRNA expression profile (4) In previous reports, predicted target genes of known tissue-specific miRNAs, such as miR-122 in liver, miR-1 in heart/skeletal muscle and miR-7 in pituitary, were expressed at significantly lower levels in their cognate tissue relative to all other tissues, corroborating the usefulness of miRNA-mRNA integrative analysis $(66,67)$. Our integrative miRNA-mRNA analysis in chondrocytes, thus, potentially provide in vitro evidence of gene regulation in addition to the in silico evidence provided by the sequence-based algorithms. The physiological and pathogenetic role of miRNAs in the 
maintenance of joint homeostasis and the development of arthritis is recently being elucidated. Dicer, a component for biogenesis of miRNAs, was found to have an essential function for skeletal development, with dicer-null growth plates showing a progressive reduction in the proliferating pool of chondrocytes, leading to severe skeletal growth defects and

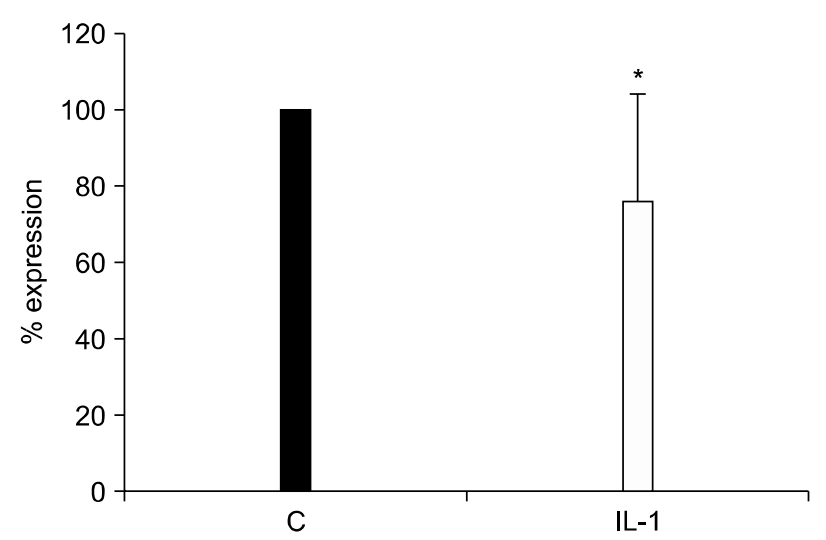

Figure 1. Real-time RT-PCR results for miR-200a in chondrocytes in response to IL- $1 \beta$. Total RNA was isolated from IL- $1 \beta$ treated monolayer chondrocytes obtained from donors different from those that were used in miRNA microarray. The RNA, U6 small nuclear 2 (RNU6-2) gene was used as a control to normalize differences in total RNA levels in each sample. The value of each control sample was set at 100 and was used to calculate the fold change in IL-1 $\beta$ treated chondrocytes. Data are from triplicate experiments using chondrocytes from 3 different donors. *denoted $\mathrm{p}<0.05$ compared to control by using Mann-Whitney U test. premature death of mice (68). In rheumatoid arthritis (RA), miR-155 was found to be overexpressed in synovial fibroblasts and this correlated with the reduced expression of MMP-3 suggesting involvement of miRNAs in the regulation of inflammation and joint destruction (69). MiR-146a is induced by a variety of microbial components and pro-inflammatory cytokines, such as IFN- $\alpha, \operatorname{IL}-1 \beta$ and TNF $\alpha$ (70). MiR-146a has been gaining interest as it was found to serve as a regulator of key signaling intermediates of the pro-inflammatory Toll-like receptor (TLR)-MyD88 pathway including IL-1 receptor-associated kinase 1 (IRAK1) and TNF receptor-associated factor 6 (TRAF6) (71). MiR-146a was

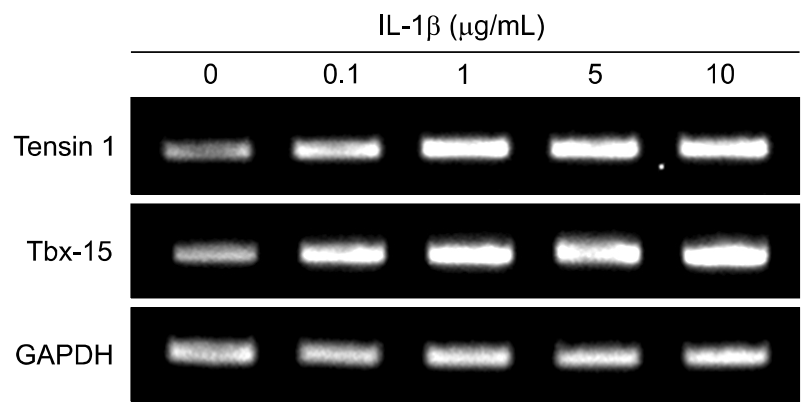

Figure 2. RT-PCR results for tensin-1 and Tbx-15 in chondrocytes in response to IL-1 $\beta$. Total RNA was isolated from IL-1 $\beta$ treated monolayer chondrocytes obtained from donors different from those that were used in mRNA microarray. GAPDH gene was used as a control to normalize differences in total RNA levels in each sample. Data are representative of duplicate experiments using chondrocytes from 3 different donors.

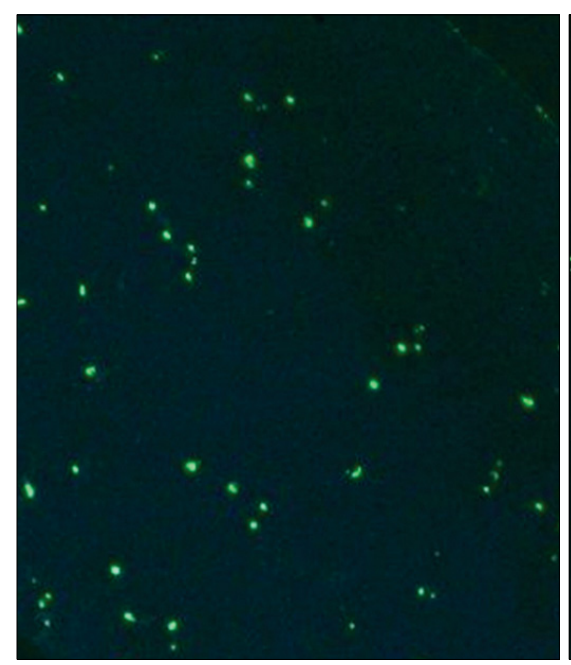

Normal

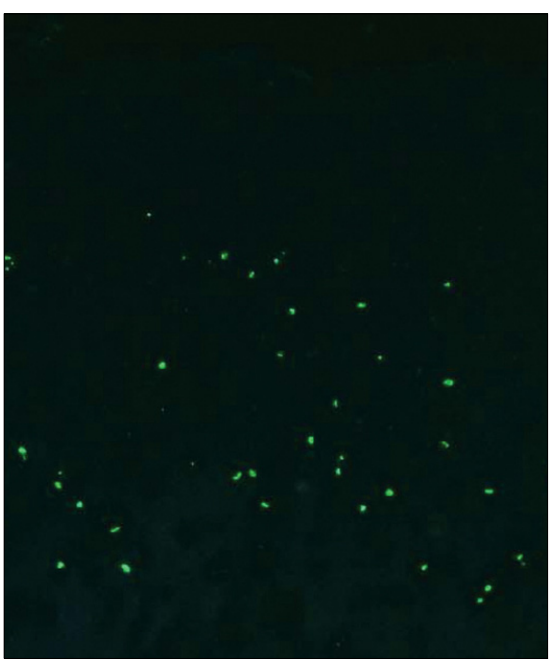

OA non-lesion

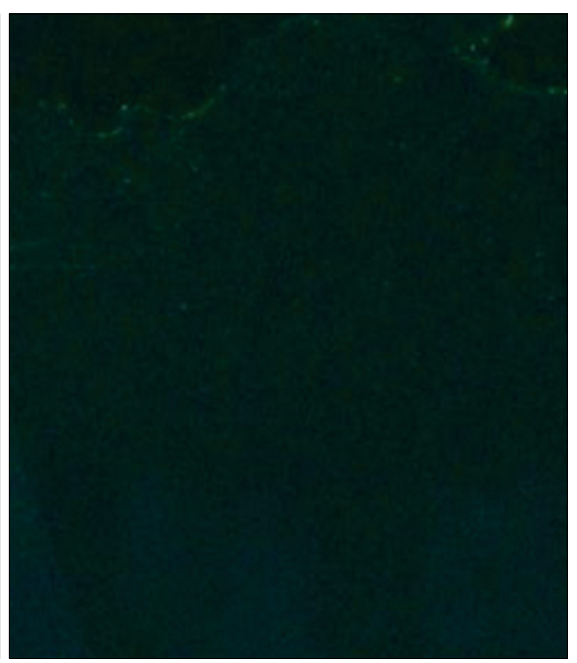

OA lesion

Figure 3. In situ hybridization for miR-200a in normal and OA cartilages. Cartilage tissues obtained from OA patients at the time of joint replacement surgery were obtained from both lesion and non-lesion areas (defined as areas with preserved cartilage surface and thickness). For normal cartilage, macro and microscopically normal cartilage samples obtained from the femoral head of patients with femoral neck fracture were used. Data are representative of specimens from 4 different donors each for normal and OA $(\times 100$, original magnification). 
overexpressed and its expression was induced by stimulation with TNF- $\alpha$ and IL-1 $\beta$ in RA synovium (72). MiR-146a was also found to be expressed in OA cartilage (73). The expression of miR-200a has not previously been reported in chondrocytes. Previous studies have shown that miR-200a plays a role in inhibition of tumorigenesis by inhibiting epithelial-to-mesenchymal transition, an initial step in tumorigenesis $(11,19,74)$. In addition, miR-200a regulate $\mathrm{Wnt} / \beta$ -catenin signaling by directly targeting the 3 ' UTR of $\beta$ -catenin mRNA, making it the first miRNA involved in the regulation of $\beta$-catenin levels (75). In our study, $\beta$-catenin was not identified as miR-200a target, which might have resulted from the limitation in microarray technique or difference in stimulating condition. Considering the role of Wnt signaling components in the maintenance and destruction of articular cartilage, investigation on the pathogenetic role of miR-200a in OA would be an interesting subject. In our in situ hybridization, miR-200a was downregulated in OA lesion cartilages compared to normal or OA non-lesion cartilage. This distribution is reciprocal of that of $\beta$ catenin, further raising the issue of miR-200a- $\beta$-catenin regulation (76).

Recent publications have reported the correlation of MMP-13, the most potent MMP implicated in the degradation of cartilage matrix, with specific miRNAs (77-80). In our study, mRNA microarray analysis revealed upregulation of MMP-13, MMP-3 and MMP 1 after 4 hours of IL- $1 \beta$ stimulation as expected(data not shown), however, we could not identify relevant miRNAs that regulate MMPs. Considering that the degree of differential expression of miRNA was modest (less than 2 fold), it is speculated that regulation of RNA degradation by miRNA may not be prominent under the condition of our experiment ( $1 \mathrm{ng} / \mu \mathrm{L}$ of IL-1 $\beta$ for 4 hours). In a report by Akhtar et al., miRNA different from ours was identified after 6 hours of $10 \mathrm{ng} / \mu \mathrm{L}$ IL- $\beta$ stimulation of OA chondrocytes, most of which were downregulated, thus treatment condition may have profound effect on the expression and regulation of miRNA in chondrocytes.

Our study has other limitations. It has been shown that some miRNAs regulate gene expression only at the protein level, and intergration of miRNA microarray and proteomic analysis would be more relevant in these cases. For example, microarray analysis of Dicer-null chondrocytes showed limited expression changes in miRNA-target genes, suggesting that chondrocytic miRNAs do not directly regulate target RNA abundance. Although it is difficult to validate miRNA target predictions from effects on translation due to the technical difficulties of genome-wide quantitative protein profiling, one report integrated genetic, bioinformatic and proteomic ap- proaches in an attempt to identify new genes and their collaborative networks involved in OA pathogenesis (77). Integration of miRNA and proteomic data with miRNA gene-target prediction algorithms generated a potential "interactome" network consisting of 11 miRNAs and 58 proteins linked by 414 potential functional associations, suggesting the feasibility of such an approach.

\section{Conclusion}

miRNAs regulated by IL- $\beta$ were identified in human articular chondrocytes along with mRNAs they regulate by using integrative miRNA-mRNA analysis. MiR-200a were found to be expressed in human OA and normal cartilages, with downregulation in $\mathrm{OA}$ lesion cartilages. It is suggested that miRNAs may play a role in the regulation of cartilage degradation in OA.

\section{Acknowledgements}

This study was supported by a grant from the Korea Healthcare Technology R\&D Project, Ministry of Health, Welfare \& Family affairs (A084026).

\section{References}

1. Goldring MB. The role of the chondrocyte in osteoarthritis. Arthritis Rheum 2000;43:1916-26.

2. Daheshia M, Yao JQ. The interleukin 1beta pathway in the pathogenesis of osteoarthritis. J Rheumatol 2008;35: 2306-12.

3. Engels BM, Hutvagner G. Principles and effects of microRNA-mediated post-transcriptional gene regulation. Oncogene 2006;25:6163-9.

4. Arora A, Simpson DA. Individual mRNA expression profiles reveal the effects of specific microRNAs. Genome Biol 2008;9:R82.

5. Sato F, Tsuchiya S, Meltzer SJ, Shimizu K. MicroRNAs and epigenetics. FEBS J 2011;278:1598-609

6. Bartel DP. MicroRNAs: genomics, biogenesis, mechanism, and function. Cell 2004;116:281-97.

7. Hobert $\mathrm{O}$. Gene regulation by transcription factors and microRNAs. Science 2008;319:1785-6.

8. Huang JC, Babak T, Corson TW, Chua G, Khan S, Gallie $\mathrm{BL}$, et al. Using expression profiling data to identify human microRNA targets. Nat Methods 2007;4:1045-9.

9. Kim HA, Cho ML, Choi HY, Yoon CS, Jhun JY, Oh HJ, et al. The catabolic pathway mediated by Toll-like receptors in human osteoarthritic chondrocytes. Arthritis Rheum 2006;54:2152-63.

10. Benjamini Y, Hochberg Y. Controlling the false discovery rate: a practical and powerful approach to multiple testing. J R Statisti Soc B 1995;57:289-300.

11. John B, Enright AJ, Aravin A, Tuschl T, Sander C, Marks DS. Human MicroRNA targets. PLoS Biol 2004;2:e363. 12. Tallheden T, Karlsson C, Brunner A, Van Der Lee J, 
Hagg R, Tommasini R, et al. Gene expression during redifferentiation of human articular chondrocytes. Osteoarthritis Cartilage 2004;12:525-35.

13. Isomäki $\mathrm{P}$, Alanärä $\mathrm{T}$, Isohanni $\mathrm{P}$, Lagerstedt $\mathrm{A}$, Korpela $\mathrm{M}$, Moilanen T, et al. The expression of SOCS is altered in rheumatoid arthritis. Rheumatology (Oxford) 2007;46: 1538-46.

14. Kan A, Ikeda T, Saito T, Yano F, Fukai A, Hojo H, et al. Screening of chondrogenic factors with a real-time fluorescence-monitoring cell line ATDC5-C2ER: identification of sorting nexin 19 as a novel factor. Arthritis Rheum 2009;60:3314-23.

15. Badariotti F, Kypriotou M, Lelong C, Dubos MP, Renard E, Galera $\mathrm{P}$, et al. The phylogenetically conserved molluscan chitinase-like protein 1 ( $\mathrm{Cg}$-Clp1), homologue of human HC-gp39, stimulates proliferation and regulates synthesis of extracellular matrix components of mammalian chondrocytes. J Biol Chem 2006;281:29583-96.

16. Maneiro E, López-Armada MJ, de Andres MC, Caramés B, Martín MA, Bonilla A, et al. Effect of nitric oxide on mitochondrial respiratory activity of human articular chondrocytes. Ann Rheum Dis 2005;64:388-95.

17. Albrecht AN, Schwabe GC, Stricker S, Böddrich A, Wanker EE, Mundlos S. The synpolydactyly homolog (spdh) mutation in the mouse -- a defect in patterning and growth of limb cartilage elements. Mech Dev 2002;112: 53-67.

18. Sironen RK, Karjalainen HM, Törrönen K, Elo MA, Kaarniranta K, Takigawa M, et al. High pressure effects on cellular expression profile and mRNA stability. A cDNA array analysis. Biorheology 2002;39:111-7.

19. Karjalainen HM, Sironen RK, Elo MA, Kaarniranta K, Takigawa M, Helminen HJ, et al. Gene expression profiles in chondrosarcoma cells subjected to cyclic stretching and hydrostatic pressure. A cDNA array study. Biorheology 2003;40:93-100.

20. Mienaltowski MJ, Huang L, Stromberg AJ, MacLeod JN. Differential gene expression associated with postnatal equine articular cartilage maturation. BMC Musculoskelet Disord 2008;9:149.

21. Millward-Sadler SJ, Khan NS, Bracher MG, Wright MO, Salter DM. Roles for the interleukin-4 receptor and associated JAK/STAT proteins in human articular chondrocyte mechanotransduction. Osteoarthritis Cartilage 2006;14: 991-1001.

22. Lee CR, Sakai D, Nakai T, Toyama K, Mochida J, Alini $\mathrm{M}$, et al. A phenotypic comparison of intervertebral disc and articular cartilage cells in the rat. Eur Spine $\mathrm{J}$ 2007; 16:2174-85.

23. Yamaoka $H$, Nishizawa S, Asawa $Y$, Fujihara $Y$, Ogasawara T, Yamaoka $\mathrm{K}$, et al. Involvement of fibroblast growth factor 18 in dedifferentiation of cultured human chondrocytes. Cell Prolif 2010;43:67-76.

24. Moore EE, Bendele AM, Thompson DL, Littau A, Waggie KS, Reardon B, et al. Fibroblast growth factor-18 stimulates chondrogenesis and cartilage repair in a rat model of injury-induced osteoarthritis. Osteoarthritis
Cartilage 2005;13:623-31.

25. Hiscock DR, Caterson B, Flannery CR. Expression of hyaluronan synthases in articular cartilage. Osteoarthritis Cartilage 2000;8:120-6.

26. Long D, Blake S, Song XY, Lark M, Loeser RF. Human articular chondrocytes produce IL-7 and respond to IL-7 with increased production of matrix metalloproteinase-13. Arthritis Res Ther 2008;10:R23.

27. Nifuji A, Miura N, Kato N, Kellermann O, Noda M. Bone morphogenetic protein regulation of forkhead/winged helix transcription factor Foxc2 (Mfh1) in a murine mesodermal cell line $\mathrm{C} 1$ and in skeletal precursor cells. J Bone Miner Res 2001;16:1765-71.

28. Bursell L, Woods A, James CG, Pala D, Leask A, Beier F. Src kinase inhibition promotes the chondrocyte phenotype. Arthritis Res Ther 2007;9:R105.

29. Wang Y, Toury R, Hauchecorne M, Balmain N. Expression and subcellular localization of the Myc superfamily proteins: c-Myc, Max, Mad1 and Mxi1 in the epiphyseal plate cartilage chondrocytes of growing rats. Cell Mol Biol (Noisy-le-grand) 1997;43:175-88.

30. Aguilar A, Wu S, De Luca F. P450 oxidoreductase expressed in rat chondrocytes modulates chondrogenesis via cholesterol- and Indian Hedgehog-dependent mechanisms. Endocrinology 2009;150:2732-9.

31. Lefebvre V, Smits P. Transcriptional control of chondrocyte fate and differentiation. Birth Defects Res C Embryo Today 2005;75:200-12.

32. Watanabe Y, Namba A, Honda K, Aida Y, Matsumura $\mathrm{H}$, Shimizu O, et al. IL-1beta stimulates the expression of prostaglandin receptor EP4 in human chondrocytes by increasing production of prostaglandin E2. Connect Tissue Res 2009;50:186-93.

33. Li X, Ellman M, Muddasani P, Wang JH, Cs-Szabo G, van Wijnen AJ, et al. Prostaglandin E2 and its cognate EP receptors control human adult articular cartilage homeostasis and are linked to the pathophysiology of osteoarthritis. Arthritis Rheum 2009;60:513-23.

34. Otsuka S, Aoyama T, Furu M, Ito K, Jin Y, Nasu A, et al. PGE2 signal via EP2 receptors evoked by a selective agonist enhances regeneration of injured articular cartilage. Osteoarthritis Cartilage 2009;17:529-38.

35. Barre PE, Redini F, Boumediene K, Vielpeau C, Pujol JP. Semiquantitative reverse transcription-polymerase chain reaction analysis of syndecan- 1 and -4 messages in cartilage and cultured chondrocytes from osteoarthritic joints. Osteoarthritis Cartilage 2000;8:34-43.

36. Echtermeyer F, Bertrand J, Dreier R, Meinecke I, Neugebauer K, Fuerst M, et al. Syndecan-4 regulates ADAMTS-5 activation and cartilage breakdown in osteoarthritis. Nat Med 2009;15:1072-6.

37. Zhang L, Yang M, Yang D, Cavey G, Davidson P, Gibson G. Molecular interactions of MMP-13 C-terminal domain with chondrocyte proteins. Connect Tissue Res 2010;51:230-9.

38. Matsui-Yuasa I, Otani S, Morisawa S, Takigawa M, Enomoto M, Suzuki F. Induction of spermidine/spermine 
N1-acetyltransferase by parathyroid hormone in rabbit costal chondrocytes in culture. J Biochem 1985;97:387-90.

39. Amraei M, Jia Z, Reboul P, Nabi IR. Acid-induced conformational changes in phosphoglucose isomerase result in its increased cell surface association and deposition on fibronectin fibrils. J Biol Chem 2003;278:38935-41.

40. Vaillancourt F, Fahmi H, Shi Q, Lavigne P, Ranger $\mathrm{P}$, Fernandes JC, et al. 4-Hydroxynonenal induces apoptosis in human osteoarthritic chondrocytes: the protective role of glutathione-S-transferase. Arthritis Res Ther 2008;10:R107.

41. Grimmer C, Balbus N, Lang U, Aigner T, Cramer T, Müller L, et al. Regulation of type II collagen synthesis during osteoarthritis by prolyl-4-hydroxylases: possible influence of low oxygen levels. Am J Pathol 2006;169: 491-502.

42. Iwamoto M, Jikko A, Murakami H, Shimazu A, Nakashima $\mathrm{K}$, Iwamoto $\mathbf{M}$, et al. Changes in parathyroid hormone receptors during chondrocyte cytodifferentiation. J Biol Chem 1994;269:17245-51.

43. Sanchez C, Deberg MA, Piccardi N, Msika P, Reginster JY, Henrotin YE. Subchondral bone osteoblasts induce phenotypic changes in human osteoarthritic chondrocytes. Osteoarthritis Cartilage 2005; 13:988-97.

44. Mizuta H, Kudo S, Nakamura E, Takagi K, Hiraki Y. Expression of the PTH/PTHrP receptor in chondrogenic cells during the repair of full-thickness defects of articular cartilage. Osteoarthritis Cartilage 2006;14:944-52.

45. Guo J, Chung UI, Yang D, Karsenty G, Bringhurst FR, Kronenberg HM. PTH/PTHrP receptor delays chondrocyte hypertrophy via both Runx2-dependent and -independent pathways. Dev Biol 2006;292:116-28.

46. Meredith D, Gehl KA, Seymour J, Ellory JC, Wilkins RJ. Characterization of sulphate transporters in isolated bovine articular chondrocytes. J Orthop Res 2007;25:1145-53.

47. Rossi F, MacLean HE, Yuan W, Francis RO, Semenova E, Lin CS, et al. p107 and p130 Coordinately regulate proliferation, Cbfa1 expression, and hypertrophic differentiation during endochondral bone development. Dev Biol 2002;247:271-85.

48. Laplantine E, Rossi F, Sahni M, Basilico C, Cobrinik D. FGF signaling targets the pRb-related p107 and p130 proteins to induce chondrocyte growth arrest. J Cell Biol 2002;158:741-50.

49. Hummert TW, Schwartz Z, Sylvia VL, Dean DD, Boyan BD. Stathmin levels in growth plate chondrocytes are modulated by vitamin D3 metabolites and transforming growth factor-beta1 and are associated with proliferation. Endocrine 2001;15:93-101.

50. Selleri L, Depew MJ, Jacobs Y, Chanda SK, Tsang KY, Cheah KS, et al. Requirement for Pbx1 in skeletal patterning and programming chondrocyte proliferation and differentiation. Development 2001;128:3543-57.

51. Vinall RL, Lo SH, Reddi AH. Regulation of articular chondrocyte phenotype by bone morphogenetic protein 7 , interleukin 1, and cellular context is dependent on the cytoskeleton. Exp Cell Res 2002;272:32-44.
52. Singh MK, Petry M, Haenig B, Lescher B, Leitges M, Kispert A. The T-box transcription factor Tbx15 is required for skeletal development. Mech Dev 2005;122:131-44.

53. Polur I, Lee PL, Servais JM, Xu L, Li Y. Role of HTRA1, a serine protease, in the progression of articular cartilage degeneration. Histol Histopathol 2010;25:599-608.

54. Chamberland A, Wang E, Jones AR, Collins-Racie LA, LaVallie ER, Huang Y, et al. Identification of a novel HtrA1-susceptible cleavage site in human aggrecan: evidence for the involvement of HtrA1 in aggrecan proteolysis in vivo. J Biol Chem 2009;284:27352-9.

55. Krejci P, Prochazkova J, Smutny J, Chlebova K, Lin P, Aklian A, et al. FGFR3 signaling induces a reversible senescence phenotype in chondrocytes similar to oncogene-induced premature senescence. Bone 2010;47:102-10.

56. Kim JS, Ryoo ZY, Chun JS. Cytokine-like 1 (Cyt11) regulates the chondrogenesis of mesenchymal cells. J Biol Chem 2007;282:29359-67.

57. Massip L, Ectors F, Deprez P, Maleki M, Behets C, Lengelé $\mathrm{B}$, et al. Expression of Hoxa2 in cells entering chondrogenesis impairs overall cartilage development. Differentiation 2007;75:256-67.

58. Mathy-Hartert M, Hogge L, Sanchez C, Deby-Dupont G, Crielaard JM, Henrotin Y. Interleukin-1beta and interleukin- 6 disturb the antioxidant enzyme system in bovine chondrocytes: a possible explanation for oxidative stress generation. Osteoarthritis Cartilage 2008;16:756-63.

59. Kolupaeva V, Laplantine E, Basilico C. PP2A-mediated dephosphorylation of p107 plays a critical role in chondrocyte cell cycle arrest by FGF. PLoS One 2008;3:e3447.

60. Parker WL, Goldring MB, Philip A. Endoglin is expressed on human chondrocytes and forms a heteromeric complex with betaglycan in a ligand and type II TGFbeta receptor independent manner. J Bone Miner Res 2003;18:289-302.

61. Church V, Yamaguchi K, Tsang P, Akita K, Logan C, Francis-West P. Expression and function of Bapx1 during chick limb development. Anat Embryol (Berl) 2005;209: 461-9.

62. Konttinen YT, Mandelin J, Li TF, Salo J, Lassus J, Liljeström M, et al. Acidic cysteine endoproteinase cathepsin $\mathrm{K}$ in the degeneration of the superficial articular hyaline cartilage in osteoarthritis. Arthritis Rheum 2002;46: 953-60.

63. Morko JP, Söderström M, Säämänen AM, Salminen HJ, Vuorio EI. Up regulation of cathepsin $\mathrm{K}$ expression in articular chondrocytes in a transgenic mouse model for osteoarthritis. Ann Rheum Dis 2004;63:649-55.

64. Connor JR, LePage C, Swift BA, Yamashita D, Bendele AM, Maul D, et al. Protective effects of a cathepsin K inhibitor, SB-553484, in the canine partial medial meniscectomy model of osteoarthritis. Osteoarthritis Cartilage 2009;17:1236-43.

65. Lewis BP, Burge CB, Bartel DP. Conserved seed pairing, often flanked by adenosines, indicates that thousands of human genes are microRNA targets. Cell 2005;120:15-20.

66. Sood P, Krek A, Zavolan M, Macino G, Rajewsky N. Celltype-specific signatures of microRNAs on target mRNA 
expression. Proc Natl Acad Sci U S A 2006;103:2746-51.

67. Farh KK, Grimson A, Jan C, Lewis BP, Johnston WK, Lim LP, et al. The widespread impact of mammalian MicroRNAs on mRNA repression and evolution. Science 2005;310:1817-21.

68. Kobayashi T, Lu J, Cobb BS, Rodda SJ, McMahon AP, Schipani E, et al. Dicer-dependent pathways regulate chondrocyte proliferation and differentiation. Proc Natl Acad Sci U S A 2008;105:1949-54.

69. Stanczyk J, Pedrioli DM, Brentano F, Sanchez-Pernaute $\mathrm{O}$, Kolling C, Gay RE, et al. Altered expression of MicroRNA in synovial fibroblasts and synovial tissue in rheumatoid arthritis. Arthritis Rheum 2008;58:1001-9.

70. Taganov KD, Boldin MP, Chang KJ, Baltimore D. NFkappaB-dependent induction of microRNA miR-146, an inhibitor targeted to signaling proteins of innate immune responses. Proc Natl Acad Sci U S A 2006;103:12481-6.

71. Luo X, Tsai LM, Shen N, Yu D. Evidence for microRNA-mediated regulation in rheumatic diseases. Ann Rheum Dis 2010;69 Suppl 1:i30-6.

72. Nakasa T, Miyaki S, Okubo A, Hashimoto M, Nishida $\mathrm{K}$, Ochi M, et al. Expression of microRNA-146 in rheumatoid arthritis synovial tissue. Arthritis Rheum 2008; 58:1284-92.

73. Yamasaki K, Nakasa T, Miyaki S, et al. Expression of MicroRNA-146a in osteoarthritis cartilage. Arthritis Rheum 2009;60:1035-41.

74. DelCarlo M, Loeser RF. Chondrocyte cell death mediated by reactive oxygen species-dependent activation of PKC-betaI. Am J Physiol Cell Physiol 2006;290:C802-11. 75. Saydam O, Shen Y, Würdinger T, Senol O, Boke E, James MF, et al. Downregulated microRNA-200a in meningiomas promotes tumor growth by reducing E-cadherin and activating the Wnt/beta-catenin signaling pathway. Mol Cell Biol 2009;29:5923-40.

76. Chun JS, Oh H, Yang S, Park M. Wnt signaling in cartilage development and degeneration. BMB Rep 2008;41: 485-94.

77. Iliopoulos D, Malizos KN, Oikonomou P, Tsezou A. Integrative microRNA and proteomic approaches identify novel osteoarthritis genes and their collaborative metabolic and inflammatory networks. PLoS One 2008;3:e3740.

78. Jones SW, Watkins G, Le Good N, Roberts S, Murphy CL, Brockbank SM, et al. The identification of differentially expressed microRNA in osteoarthritic tissue that modulate the production of TNF-alpha and MMP13. Osteoarthritis Cartilage 2009;17:464-72.

79. Akhtar N, Rasheed Z, Ramamurthy S, Anbazhagan AN, Voss FR, Haqqi TM. MicroRNA-27b regulates the expression of matrix metalloproteinase 13 in human osteoarthritis chondrocytes. Arthritis Rheum 2010;62:1361-71.

80. Tardif G, Hum D, Pelletier JP, Duval N, Martel-Pelletier J. Regulation of the IGFBP-5 and MMP-13 genes by the microRNAs miR-140 and miR-27a in human osteoarthritic chondrocytes. BMC Musculoskelet Disord 2009; 10:148. 